Authors' contribution/

Wkład autorów:

A. Zaplanowanie badań/

Study design

B. Zebranie danych/

Data collection

C. Analiza statystyczna/

Statistical analysis

D. Interpretacja danych/

Data interpretation

E. Przygotowanie tekstu/

Manuscript preparation

F. Opracowanie

piśmiennictwa/

Literature search

G. Pozyskanie funduszy/

Funds collection
ISSN 2083-3725

\section{ANALYSIS OF APPEAL PROCEDURE FOR CO-FINANCING OF TOURISM PROJECTS UNDER REGIONAL OPERATIONAL PROGRAMME FOR PODLASKIE PROVINCE 2007-2013}

\section{ANALIZA PROCEDURY ODWOŁAWCZEJ W ZAKRESIE DOFINANSOWANIA PROJEKTÓW TURYSTYCZNYCH W RAMACH REGIONALNEGO PROGRAMU OPERACYJNEGO WOJEWÓDZTWA PODLASKIEGO 2007-2013}

\author{
Sławomir J. Snarski ${ }^{1(A, B, C, D, E, F, G)}$, Marek Martyniuk ${ }^{2}(\mathrm{~A}, \mathrm{~B}, \mathrm{C}, \mathrm{D}, \mathrm{E}, \mathrm{F}, \mathrm{G})$
}

${ }^{1}$ Bialystok University of Technology, Faculty of Forestry in Hajnówka

Politechnika Białostocka, Zamiejscowy Wydział Leśny w Hajnówce

${ }^{2}$ University of Bialystok, Faculty of Law/Uniwersytet w Białymstoku, Wydział Prawa

Snarski S.J., Martyniuk M. (2017), Analysis of appeal procedure for co-financing of tourism projects under Regional Operational Programme for Podlaskie Province 2007-2013/ Analiza procedury odwoławczej $w$ zakresie dofinansowania projektów turystycznych w ramach Regionalnego Programu Operacyjnego Województwa Podlaskiego 2007-2013. Economic and Regional Studies. Vol. 10, No. 1, pp. 75-84. https://doi.org/10.2478/ers-2017-0006

\section{Summary}

Subject and purpose of work: Research targeted at verification of the effectiveness of the appeal procedure for co-financing of tourism projects under the ROPPV 2007-2013 has been presented in the article.

Materials and methods: The article is based on the analysis of the secondary data collected by the Podlaskie Province Marshal's Office in Bialystok and the literature covering the research area. The analysis of detailed information was performed using inductive inference.

Results: None of the applicants under Priority Axis III. Tourism and culture development ROPPV 20072013 decided to exercise their right regarding the use of the judicial stage of the appeal procedure. Conclusions: It is impossible to clearly determine the degree of effectiveness of the appeal procedure concerning the process of application for the co-financing of tourism projects under the ROPPV 20072013 because the mechanism of verification of the correctness of projects' assessment was not applied in its full extent.

Keywords: regional operational programme, appeal procedure, tourism

\section{Streszczenie}

Przedmiot i cel pracy: W artykule przedstawiono badania mające na celu weryfikację skuteczności procedury odwoławczej w zakresie ubiegania się o dofinansowanie projektów turystycznych $\mathrm{w}$ ramach RPO WP 2007-2013.

Materiały i metody: W badaniach wykorzystano analizę danych wtórnych pochodzących z Urzędu Marszałkowskiego Województwa Podlaskiego w Białymstoku oraz literatury z dziedziny objętej obszarem badawczym. Analiza informacji jednostkowych dokonana została z zastosowaniem wnioskowania indukcyjnego.

Wyniki: Żaden z wnioskodawców w ramach Osi priorytetowej III. Rozwój turystyki i kultury RPOWP 2007-2013 nie zdecydował się na realizację swego uprawnienia w zakresie skorzystania z etapu sądowego procedury odwoławczej.

Wnioski: Nie da się jednoznacznie określić stopnia skuteczności procedury odwoławczej w przedmiocie ubiegania się o dofinansowanie projektów turystycznych w ramach RPO WP 2007-2013 jako mechanizmu weryfikacji prawidłowości przeprowadzenia oceny projektów, gdyż nie miała ona zastosowania w pełnym zakresie.

Słowa kluczowe: regionalny program operacyjny, procedura odwoławcza, turystyka

Address for correspondence/ Adres korespondencyjny: dr inż. Sławomir J. Snarski, Zamiejscowy Wydział Leśny Politechniki Białostockiej, ul. Piłsudskiego 8, 17-200 Hajnówka, Polska; tel. +48 85 682-95-00; e-mail: s.snarski@pb.edu.pl; mgr Marek Martyniuk, Uniwersytet w Białymstoku, Wydział Prawa, ul. Mickiewicza 1, 15-213 Białystok, Polska; tel. +488574572 01; e-mail: marek.martyniuk1@gmail.com.

Journal indexed in/ Czasopismo indeksowane w: AgEcon Search, AGRO, BazEkon, Index Copernicus Journal Master List, ICV 2015: 81,26; Polish Ministry of Science and Higher Education 2016: 9 points/ AgEcon Search, AGRO, BazEkon, Index Copernicus Journal Master List ICV 2015: 81,26; Ministerstwie Nauki i Szkolnictwa Wyższego 2016: 9 punktów. Copyright: (C) 2016 Pope John Paul II State School of Higher Education in Biała Podlaska, Sławomir J. Snarski, Marek Martyniuk. All articles are distributed under the terms of the Creative Commons Attribution-NonCommercial-ShareAlike 4.0 International (CC BY-NC-SA 4.0) License (http://creativecommons.org/licenses/bync-sa/4.0/), allowing third parties to copy and redistribute the material in any medium or format and to remix, transform, and build upon the material, provided the original work is properly cited and states its license. 


\section{Introduction}

The Regional Operational Programme for Podlaskie Province 2007-2013 (hereinafter referred to as "the ROPPV") was approved by the Board of Podlaskie Province on 9 November 2007 through the Resolution No. 46/599/07. It was one of the instruments for fulfilling the objectives of the National Strategic Reference Framework 20072013 - a document defining national priorities and the allocation of a substantial part of the European funds under the cohesion policy in the 2007-2013 programming period (Dziurbejko et al. 2010). According to the Podlaskie Province Development Strategy 2020 of 30 January 2006, the development of tourism with the use of natural and cultural heritage was recognized as one of the main strategic objectives of the region's development. Therefore, the Board of Podlaskie Province, performing the function of the Managing Authority of the ROPPV, established Priority Axis III. Tourism and culture development and allocated the amount of PLN 555,342,985.45 to support the widely understood tourism industry by part-financing eligible costs of 117 projects. However, in compliance with the Interim Implementation Report of the ROPPV for the 1st Half of 2015, within the same priority axis from the beginning of the programme to 30 June 2015 as many as 128 applications for funding of a total value of PLN 1,040,123,360.94 were rejected by the Managing Authority.

Taking into consideration the amount of funds disbursed on the development of tourism in the region and the rejection of such a large number of projects in this field, the purpose of this article is an attempt to verify the effectiveness of the appeal procedure for co-financing of tourism projects under the ROPPV 2007-2013. Therefore, the main content of the article was structured into two main parts. The first part presents the general rules of the implementation of tourism projects under Priority Axis III. Tourism and culture development. The second part of the article describes the appeal procedure applicable to the calls for proposals in the field of tourism within the programme in an attempt to determine the degree of its effectiveness. The article is based on the analysis of the secondary data collected by the Podlaskie Province Marshal's Office in Bialystok - mainly in the form of programme documents, interim reports on the implementation of the programme and the data made available in accordance with art. $10 \S 1$ of the Act of 6 September 2001 on Access to Public Information (Journal of Laws of 2015, item 2058, as amended) - and the literature covering the research area.

\section{Materials and methods}

In compliance with the Decision of the European Commission No. C(2013)9267 of 17 December 2013, the total budget of the programme amounted to EUR 895,148,497.00, of which the amount of EUR $672,542,971.00$ was from the European Regional

\section{Wstęp}

Regionalny Program Operacyjny Województwa Podlaskiego na lata 2007-2013 (dalej: RPOWP) został przyjęty przez Zarząd Województwa Podlaskiego dnia 9 listopada 2007 r. w drodze Uchwały $\mathrm{Nr}$ 46/599/07. Był on jednym $\mathrm{z}$ instrumentów realizujacych cele Narodowych Strategicznych Ram Odniesienia na lata 2007-2013, czyli dokumentu definiującego krajowe priorytety, na które została przeznaczona zasadnicza część funduszy europejskich w ramach polityki spójności w okresie programowania 20072013 (Dziurbejko i in. 2010). W Strategii Rozwoju Województwa Podlaskiego do roku 2020 z dnia 30 stycznia 2006 r. rozwój turystyki z wykorzystaniem walorów przyrodniczych i dziedzictwa kulturowego został uznany za jeden z głównych celów strategicznych w rozwoju regionu. Dlatego też Zarząd Województwa Podlaskiego w ramach RPOWP wydzielił Oś priorytetową III. Rozwój turystyki i kultury oraz przeznaczył na wsparcie szeroko rozumianej turystyki kwotę 555.342.985,45 zł poprzez dofinansowanie 117 projektów. Jednocześnie, zgodnie ze Sprawozdaniem okresowym z realizacji RPOWP za I półrocze 2015 r., w ramach tej samej osi priorytetowej od początku realizacji programu do dnia 30 czerwca 2015 r. zostało odrzuconych aż 128 wniosków o dofinansowanie o wartości ogółem 1.040.123.360,94 zł.

Biorąc pod uwagę wielkość środków finansowych wydatkowanych na rozwój turystyki w regionie oraz odrzucenie tak dużej ilości projektów z tego zakresu, celem niniejszego artykułu jest próba weryfikacji skuteczności procedury odwoławczej w przedmiocie ubiegania się o dofinansowanie projektów turystycznych w ramach RPO WP 2007-2013. Z tego względu zasadnicza treść artykułu została podzielona na dwie części. W części pierwszej zostały przedstawione ogólne zasady wdrażania projektów z zakresu turystyki w ramach Osi priorytetowej III. Rozwój turystyki i kultury, z uwzględnieniem konkursowej i pozakonkursowej procedury naboru wniosków o dofinansowanie. Druga część artykułu zawiera opis procedury odwoławczej mającej zastosowanie do przeprowadzonych konkursów w zakresie ubiegania się o dofinansowanie projektów turystycznych w ramach RPOWP oraz próbę określenia stopnia jej skuteczności. Artykuł opiera się na analizie danych wtórnych pochodzących z Urzędu Marszałkowskiego Województwa Podlaskiego w Białymstoku - przede wszystkim w formie dokumentów programowych, sprawozdań okresowych z realizacji RPOWP i danych udostepnionych $\mathrm{w}$ trybie art. 10 ust. 1 ustawy z dnia 6 września 2001 r. o dostępie do informacji publicznej (Dz.U. z 2015 r. poz. 2058, z późn. zm.) - oraz literatury z dziedziny objętej obszarem badawczym.

\section{Materiały i metody}

RPOWP składał się z 7 osi priorytetowych. Łączna kwota środków finansowych na realizację programu wyniosła 895.148.497,00 euro, z czego kwota 672.542.971,00 euro, zgodnie z decyzją Komisji Europejskiej C(2013)9267 z dnia 17 grudnia 2013 r., po- 
Development Fund. The overall objective of the ROPPV was to increase economic growth and create new non-agricultural workplaces while preserving the natural and cultural heritage of the region. The aforementioned objective was being achieved by means of three specific objectives, including the third specific objective, id est the development of tourism with the use of natural and cultural heritage. In accordance with the ROPPV assumptions, the practical implementation of this specific objective was ensured by supporting investments focused on the creation of an integrated package of tourist services resulting in greater diversification and extension of the tourist season in Podlaskie Province.

The programme was composed of seven priority axes. The priority axis, which to the greatest extent focused on increasing the tourist attractiveness of the region was Priority Axis III. Tourism and culture development. It comprised two measures: 3.1. Development of regional tourism attractiveness and 3.2 Investment support for tourism enterprises.

According to the provisions of the Detailed Description of Priority Axes of Regional Operational Programme for Podlaskie Province 2007-2013, Measure 3.1 was intended to boost tourism and the attractiveness of the Podlaskie region in comparison with other regions of the country. It involved encouraging investment in culture and tourism (including recreation and sport facilities as well as exhibition and conference centres) and promoting the Podlaskie region as an attractive place for tourism. In addition, the support could be granted for the creation of facilities enabling the organization of mass events, attracting tourists from outside the region (e.g. football stadiums, sports halls, facilities for swimming) and activities in the field of construction and renovation of cultural facilities. Investments in this regard could be implemented in the areas designated by the Board of Podlaskie Province as attractive tourist destinations.

The list of potential beneficiaries of Measure 3.1 included regional and local authorities, nongovernmental organizations, state administration, entrepreneurs, the State Forests National Forest Holding, national and landscape parks, churches and religious associations. Financial allocation for the measure amounted to a total of EUR 103,371,397.00. Within the period of programme implementation, there were carried out 4 calls for proposals, while 9 applications were classified as individual key projects and received direct support. According to the Interim Implementation Report of the ROPPV for the 1st Half of 2015, as at 30 June 2015, within the framework of the measure 61 projects were approved for implementation of a total value of PLN $842,746,905.95$, including PLN 406,878,722.90 of cofunding from the programme, as shown in table 1. chodziła z Europejskiego Funduszu Rozwoju Regionalnego. Celem głównym RPOWP było zwiększenie tempa wzrostu gospodarczego i tworzenie nowych pozarolniczych miejsc pracy przy poszanowaniu i zachowaniu dziedzictwa przyrodniczego i kulturowego regionu. Powyższy cel realizowany był za pomocą trzech celów szczegółowych, w tym celu szczegółowego 3: Rozwój turystyki z wykorzystaniem walorów przyrodniczych i dziedzictwa kulturowego. Z kolei implementacja celu szczegółowego 3, zgodnie z założeniami RPOWP, odbywała się poprzez wsparcie inwestycji koncentrujących się na stworzeniu zintegrowanego pakietu atrakcji turystycznych skutkujących większą dywersyfikacją usług i wydłużeniu sezonu turystycznego $\mathrm{w}$ regionie.

Osią priorytetową, która w największym stopniu koncentrowała się na zwiększeniu atrakcyjności turystycznej województwa podlaskiego, była Oś priorytetowa III. Rozwój turystyki i kultury. Składała się ona z dwóch działań: 3.1. Rozwój atrakcyjności turystycznej regionu oraz 3.2 Wsparcie inwestycyjne przedsiębiorstw z branży turystycznej.

Zgodnie ze Szczegółowym Opisem Priorytetów Regionalnego Programu Operacyjnego Województwa Podlaskiego na lata 2007-2013, celem Działania 3.1 był wzrost atrakcyjności i konkurencyjności turystycznej województwa podlaskiego w stosunku do innych regionów kraju. W ramach rozwoju atrakcyjności turystycznej regionu o współfinansowane mogły ubiegać się przedsięwzięcia z zakresu infrastruktury kulturalnej i turystycznej (polegające na realizacji projektów m.in. z zakresu infrastruktury sportowej i rekreacyjnej jak też tworzenia centrów wystawienniczych i kongresowych) oraz tworzenia i rozwoju spójnego systemu promocji województwa podlaskiego. Ponadto wsparciem mogło zostać objęte tworzenie obiektów umożliwiających organizowanie imprez masowych, przyciągających turystów spoza regionu (np. stadiony piłkarskie, hale sportowe, obiekty pływackie) oraz działania z zakresu budowy i remontu obiektów kulturalnych. Inwestycje w powyższym zakresie mogły być realizowane na terenach uznanych przez Zarząd Województwa Podlaskiego za atrakcyjne turystycznie.

Beneficjentami Działania 3.1 mogły być m.in. jednostki samorządu terytorialnego, organizacje pozarządowe, administracja rządowa, przedsiębiorcy, Państwowe Gospodarstwo Leśne Lasy Państwowe, parki narodowe i krajobrazowe a także kościoły i związki wyznaniowe. Alokacja finansowa na działanie ogółem wyniosła 103.371.397 euro. W latach 2007-2013 w ramach działania zostały przeprowadzone cztery postępowania konkursowe, natomiast 9 projektów zostało zaliczonych do indywidualnych projektów kluczowych i uzyskało wsparcie w procedurze pozakonkursowej. Zgodnie ze sprawozdaniem okresowym z realizacji RPOWP za I półrocze 2015 r., wg stanu na dzień 30 czerwca 2015 r., w ramach działania do realizacji zostało zatwierdzonych 61 projektów o ogólnej wartości 842.746.905,95 zł, w tym 406.878.722,90 zł dofinansowania ze środków programu, co ilustruje tabela 1. 
Table 1. Project proposals selected for co-financing under the ROPPV 2007-2013 as at 30 June 2015 (PLN)

Tabela 1. Wnioski o dofinansowanie zatwierdzone do realizacji od początku wdrażania RPOWP 2007-2013 do dnia 30 czerwca 2015 r. (w zł)

\begin{tabular}{|c|c|r|r|r|}
\hline $\begin{array}{c}\text { Measure / sub- } \\
\text { measure/ } \\
\text { Działanie/ } \\
\text { poddziałanie }\end{array}$ & $\begin{array}{c}\text { Number of } \\
\text { applications/ } \\
\text { Liczba wniosków }\end{array}$ & $\begin{array}{c}\text { Total value/ } \\
\text { Wartość ogółem }\end{array}$ & $\begin{array}{c}\text { Eligible expenditure/ } \\
\text { Wydatki } \\
\text { kwalifikowalne }\end{array}$ & $\begin{array}{c}\text { Total public } \\
\text { contribution/ } \\
\text { Dofinansowanie }\end{array}$ \\
\hline 3.1 & 61 & $842,746,905.95$ & $781,044,777.45$ & $406,878,722.90$ \\
\hline 3.2 incl.:/ w tym: & 56 & $442,499,600.88$ & $346,743,011.67$ & $148,464,262.55$ \\
\hline-3.2 .1 & 20 & $115,892,855.65$ & $94,398,969.15$ & $47,550,101.70$ \\
\hline-3.2 .2 & 36 & $326,606,745.23$ & $252,344,042.52$ & $100,914,160.85$ \\
\hline $\begin{array}{l}\text { Total for Priority } \\
\text { Axis III/ } \\
\text { Razem dla Osi III }\end{array}$ & $\mathbf{1 1 7}$ & $\mathbf{1 , 2 8 5 , 2 4 6 , 5 0 6 . 8 3}$ & $\mathbf{1 , 1 2 7 , 7 8 7 , 7 8 9 . 1 2}$ & $\mathbf{5 5 5 , 3 4 2 , 9 8 5 . 4 5}$ \\
\hline
\end{tabular}

Source: own elaboration based on the Interim Implementation Report of Regional Operational Programme for Podlaskie Province 2007-2013 for the 1st Half of 2015, p. 9, www.rpowp.wrotapodlasia.pl (access: 18.05.2016).

Źródło: opracowanie własne na podstawie Sprawozdania okresowego z realizacji Regionalnego Programu Operacyjnego Województwa Podlaskiego na lata 2007-2013 za I półrocze 2015 r., s. 9, www.rpowp.wrotapodlasia.pl (dostęp: 18.05.2016).

Measure 3.2. Investment support for tourism enterprises consisted of two sub-measures: 3.2.1. Microenterprises and 3.2.2. Small and medium enterprises. The horizontal objective of the measure was to strengthen the tourism industry in the region by supporting enterprise development projects. In principle, it was aimed at the development of tourist accommodation and catering facilities as well as other tourist infrastructure, including projects related to the development of medical tourism. Thus, investments in accommodations could be supported only in the most attractive tourist areas, which are heavily dependent on the tourism sector due to their environmental values and the characteristics of local labour markets.

In Measure 3.2 large-scale strategic projects concerning tourism could not be implemented, so none of the tourism projects carried out by private operators was included in the Indicative List of Individual Key Projects of the ROPPV. Therefore, in the years 2007-2014 the Managing Authority of the ROPPV launched 6 calls for proposals within the measure. The financial allocation for the measure amounted to a total of EUR 34,862,516.00. The support was provided in the form of direct grants for the extension or expansion of the tourism enterprises and upgrading offered services. From the beginning of the ROPPV implementation to 30 June 2015 only 56 applications were approved by the Managing Authority. The total amount of funding provided within the measure amounted to PLN 148,464,262.55 (table 1).

Interestingly, taking into account the period from the beginning of the ROPPV implementation to 30 June 2015, Priority Axis III compared to other axes of the programme had the lowest level of fulfilment of obligations towards the European Union for the years $2007-2013$, that is $97.89 \%$. Nevertheless, the Managing Authority of the ROPPV rejected 128 project proposals of a total value of PLN 1,040,123,360.94, as shown in table 2.
Działanie 3.2. Wsparcie inwestycyjne przedsiębiorstw z branży turystycznej składało się z dwóch poddziałań: 3.2.1. Mikroprzedsiębiorstwa oraz 3.2.2. Małe i średnie przedsiębiorstwa. Celem horyzontalnym niniejszego działania było wzmocnienie branży turystycznej województwa poprzez wsparcie projektów rozwojowych przedsiębiorstw. Było ono ukierunkowane na rozbudowę bazy noclegowej regionu, bazy gastronomicznej oraz innej infrastruktury turystycznej, w tym przedsięwzięć związanych z rozwojem turystyki leczniczo-wypoczynkowej. Z założenia, inwestycje w bazę noclegową mogły być realizowane wyłącznie na obszarach najbardziej atrakcyjnych turystycznie zgodnie ze strategią rozwoju turystyki w tych gminach, które są $\mathrm{w}$ dużym stopniu zależne od sektora turystycznego ze względu na ich walory środowiskowe i gdzie można udowodnić znaczący wpływ inwestycji na lokalny rynek pracy.

W ramach Działania 3.2 żaden z projektów z zakresu turystyki realizowanych przez podmioty prywatne nie znalazł się $\mathrm{w}$ Indykatywnym Wykazie Indywidualnych Projektów Kluczowych RPOWP. W latach 2007-2014 Instytucja Zarządzająca RPOWP, przeprowadził 6 postępowań konkursowych $\mathrm{w}$ ramach Działania 3.2. Alokacja finansowa na działanie ogółem wyniosła 34.862.516,00 euro. Wsparcie to było udzielane $\mathrm{w}$ postaci dotacji bezpośrednich na rozbudowę lub rozszerzenie działalności przedsiębiorstw z branży turystycznej oraz zmianę sposobu i podwyższenie standardu świadczonych usług. Od początku wdrażania RPOWP do dnia 30 czerwca 2015 r. w ramach Działania 3.2 zatwierdzono do realizacji 56 wniosków opiewających na kwotę dofinansowania 148.464.262,55 zł (tabela 1).

Co ciekawe, biorąc pod uwagę okres od początku wdrażania RPOWP do dnia 30 czerwca 2015 r., Oś priorytetowa III, w porównaniu do pozostałych osi programu, miała najniższą wartość poziomu realizacji zobowiązań względem Unii Europejskiej na lata 20072013, tj. $97,89 \%$. Pomimo to Instytucja Zarządzająca RPOWP w ramach przeprowadzonych naborów wniosków odrzuciła aż 128 projektów o ogólnej wartości 1.040.123.360,94 zł, co zostało przedstawione w tabeli 2. 
Table 2. Project proposals rejected under the ROPPV 2007-2013 as at 30 June 2015 (PLN)

Tabela 2. Wnioski o dofinansowanie odrzucone od początku wdrażania RPOWP 2007-2013 do dnia 30 czerwca 2015 r. (w zł)

\begin{tabular}{|c|c|r|r|r|}
\hline $\begin{array}{c}\text { Measure / sub- meas- } \\
\text { ure/ } \\
\text { Działanie/ poddzia- } \\
\text { fanie }\end{array}$ & $\begin{array}{c}\text { Number of applica- } \\
\text { tions/ } \\
\text { Liczba wniosków }\end{array}$ & $\begin{array}{c}\text { Total value/ } \\
\text { Wartość ogółem }\end{array}$ & $\begin{array}{c}\text { Eligible expenditure/ } \\
\text { Wydatki kwalifiko- } \\
\text { walne }\end{array}$ & $\begin{array}{c}\text { Total public contribu- } \\
\text { tion/ } \\
\text { Dofinansowanie }\end{array}$ \\
\hline 3.1 & 56 & $616,278,228.28$ & $590,191,719.68$ & $351,586,417.38$ \\
\hline 3.2 incl.:/ w tym: & 72 & $423,845,132.66$ & $344,006,675.47$ & $162,223,363.82$ \\
\hline-3.2 .1 & 35 & $108,471,376.35$ & $85,945,065.41$ & $44,543,805.06$ \\
\hline-3.2 .2 & 37 & $315,373,756.31$ & $258,061,610.06$ & $117,679,558.76$ \\
\hline $\begin{array}{l}\text { Total for Priority } \\
\text { Axis III/ } \\
\text { Razem dla Osi III }\end{array}$ & $\mathbf{1 2 8}$ & $\mathbf{1 , 0 4 0 , 1 2 3 , 3 6 0 . 9 4}$ & $\mathbf{9 3 4 , 1 9 8 , 3 9 5 . 1 5}$ & $\mathbf{5 1 3 , 8 0 9 , 7 8 1 . 2 0}$ \\
\hline
\end{tabular}

Source: own elaboration based on the Interim Implementation Report of Regional Operational Programme for Podlaskie Province 2007-2013 for the 1st Half of 2015, p. 10, www.rpowp.wrotapodlasia.pl (access: 18.05.2016).

Źródło: opracowanie własne na podstawie Sprawozdania okresowego z realizacji Regionalnego Programu Operacyjnego Województwa Podlaskiego na lata 2007-2013 za I półrocze 2015 r., s. 10, www.rpowp.wrotapodlasia.pl (dostęp: 18.05.2016 r.).

The disbursement of such significant funds in the region accompanied by the rejection of so many applications for co-financing of tourism projects raised the question: did the process of selection of submitted applications provide the applicants with an effective appeal procedure in order to objectively assess projects and select the best of them? How many of the submitted protests and applications for reconsideration were approved? Did the appeal procedure constitute an effective instrument of verification of the quality assessment of submitted projects, or was it intended to affirm the earlier decisions made in the interest of the Managing Authority of the ROPPV? These questions and dilemmas prompted an analysis of the effectiveness of the appeal procedure in the field of applying for funding of tourism projects within the framework of the ROPPV.

\section{Results}

The scope of the appeal procedures within the implementation system of the European Union's Cohesion Policy for 2007-2013 in Poland was regulated by the Act of 6 December 2006 on the Principles of the Development Policy Making (Journal of Laws of 2016, item 383). On this basis and in accordance with the relevant guidelines of the minister responsible for regional development, the Managing Authority of the ROPPV specifically identified types of legal remedies available to the applicants during the conduct of assessment of their projects and the appeal procedure (Suwaj, Perkowski 2010). It should be noted that the appeal procedure within the ROPPV, the aim of which was to ensure the possibility of verifying the accuracy of the assessment of projects, was applicable only to the projects selected through calls for proposals. The procedure consisted of two stages: the pre-trial stage and the stage of the proceedings before the administrative courts.

In compliance with the rules of the ROPPV's implementation system, in the case of a negative assessment of a project, at the pre-trial stage an applicant was entitled to lodge to the Managing
Z uwagi na wydatkowanie tak znaczących środków w skali regionu oraz odrzucenie tylu wniosków o dofinansowanie projektów z zakresu turystyki nasuwa się pytanie: czy proces wyboru poprzedzający ewentualną implementację składanych wniosków zapewnił wnioskodawcom skuteczną procedurę odwoławczą w celu zobiektywizowania oceny projektów i wyboru najlepszych z nich? Ile ze złożonych protestów i wniosków o ponowne rozpatrzenie sprawy zostało rozpatrzonych pozytywnie? Czy procedura odwoławcza była realnym instrumentem weryfikacji jakości oceny złożonych projektów, czy też miała za zadanie faktyczną afirmację wcześniej zapadłych rozstrzygnięć w interesie Instytucji Zarządzającej RPOWP? Te pytania i dylematy dały asumpt do podjęcia analizy skuteczności procedury odwoławczej w zakresie ubiegania się o dofinansowanie projektów turystycznych w ramach RPOWP.

\section{Wyniki}

Zakres procedury odwoławczej w ramach systemu realizacji unijnej polityki spójności na lata 20072013 został uregulowany przepisami ustawy z dnia 6 grudnia 2006 r. o zasadach prowadzenia polityki rozwoju (Dz. U. z 2016 r. poz. 383). Na tej podstawie oraz zgodnie z odpowiednimi wytycznymi ministra właściwego do spraw rozwoju regionalnego, Instytucja Zarządzająca RPOWP szczegółowo określiła rodzaje środków odwoławczych przysługujących wnioskodawcy w trakcie naboru projektów oraz tryb przeprowadzania procedury odwoławczej (Suwaj, Perkowski 2010). Należy przy tym nadmienić, iż procedura odwoławcza w ramach RPOWP, której celem było zapewnienie możliwości weryfikacji prawidłowości dokonanej oceny projektów, miała zastosowanie jedynie do procesu wyboru projektów w trybie konkursowym. Składała się ona z dwóch etapów: etapu przedsądowego i etapu postępowania przed sądami administracyjnymi.

W systemie realizacji RPOWP przewidziano, że w przypadku negatywnej oceny projektu, na etapie przedsądowym wnioskodawcy przysługiwało prawo wniesienia do Instytucji Zarządzającej środków 
Authority the following legal remedies: a protest (the first pre-trial stage) and an application for reconsideration (the second pre-trial stage). In the initial phase of implementation of the ROPPV protests were dealt with by the Governor of Podlaskie Province, and were lodged through the Department for Regional Operational Programme Management of the Podlaskie Province Marshal's Office. In the case of calls for proposals announced after 20 December 2008 under the provisions of the Act of 7 November 2008 on Amending Certain Acts in Connection with the Implementation of the Structural Funds and the Cohesion Fund (Journal of Laws No. 216, item 1370), the institution responsible for considering the protests was the Department for Regional Operational Programme Management of the Podlaskie Province Marshal's Office, and applications for reconsideration were considered by the Department of Regional Policy of the aforementioned office.

The negative assessment of the project could involve both formal and quality assessment. If at any stage of the appeal procedure the allocation for implementation of the measure was exhausted, the Managing Authority of the ROPPV simply left the protest or the applications for reconsideration of the case without consideration. An appeal by the applicant did not result in holding the contract procedures concerning the applicants whose projects were recommended for co-financing (Perkowski 2010).

If the result of the re-assessment of the application for funding was positive, id est entitling to qualify for implementation, the project was placed on the list of projects assessed positively. This meant, however, only a conditional declaration of its co-financing by the Managing Authority of the ROPPV. Furthermore, if at any stage of the proceedings regarding the appeal procedure the allocation for implementation of the measure or priority was exhausted, the Managing Authority of the ROPPV left a legal remedy without consideration.

After the exhaustion of the pre-trial appeal procedure, the applicant could lodge a complaint to the competent administrative court, id est in the case of the ROPPV - to the Province Administrative Court in Bialystok. The possibility of lodging a complaint depended on exercising the available legal remedies at the pre-trial stage of the appeal procedure. As a result of consideration of the complaint, the court could: uphold the complaint, dismiss the complaint or discontinue the proceedings.

From the judgment before the Voivodship Administrative Court, both the applicant and the Managing Authority of the ROPPV could bring a cassation complaint to the Supreme Administrative Court in Warsaw. The statement by the court during the appeal indicating that the assessment of the project was carried out in a way that violated the law resulted in the need of repeating the assessment (Łacny 2015). In this situation, the Managing Authority of the ROPPV was obligated to re-review the assessment procedure. The final judgment of the administrative court, involving the dismissal odwoławczych dwojakiego rodzaju: protestu (I etap przedsądowy) oraz wniosku o ponowne rozpatrzenie sprawy (II etap przedsądowy). W początkowej fazie wdrażania systemu realizacji RPOWP protesty rozpatrywane były przez Wojewodę Podlaskiego, a ich wniesienie musiało nastąpić za pośrednictwem Departamentu Zarządzania RPO Urzędu Marszałkowskiego Województwa Podlaskiego. W przypadku konkursów ogłoszonych po 20 grudnia 2008 r., na mocy przepisów ustawy z dnia 7 listopada 2008 r. o zmianie niektórych ustaw w związku z wdrażaniem funduszy strukturalnych i Funduszu Spójności (Dz. U. $\mathrm{Nr} 216$, poz. 1370), instytucją właściwą do rozpatrywania protestów był Departament Zarządzania RPO Urzędu Marszałkowskiego Województwa Podlaskiego, natomiast wnioski o ponowne rozpatrzenie sprawy rozpatrywane były przez Departament Polityki Regionalnej tegoż urzędu.

Negatywna ocena mogła dotyczyć zarówno oceny formalnej, jak i merytorycznej projektu. W przypadku, gdy na jakimkolwiek etapie postępowania w zakresie procedury odwoławczej, alokacja na realizację działania została wyczerpana, Instytucja Zarządzająca RPOWP pozostawiała protest lub wniosek o ponowne rozpatrzenia sprawy bez rozpatrzenia. Wniesienie przez wnioskodawcę środka odwoławczego nie wstrzymywało zawierania umów z wnioskodawcami, których projekty zostały zakwalifikowane do dofinansowania (Perkowski 2010).

Jeżeli wynik ponownej oceny wniosku o dofinansowanie dokonanej wskutek rozpatrzenia wniesionego środka odwoławczego był pozytywny, tzn. uprawniający zakwalifikowanie do realizacji, projekt trafiał na listę projektów ocenionych pozytywnie, co jednak oznaczało jedynie warunkową deklarację jego dofinansowania przez Instytucję Zarządzającą RPOWP. Co więcej, w przypadku gdy na jakimkolwiek etapie postępowania w zakresie procedury odwoławczej, alokacja na realizację działania lub priorytetu została wyczerpana, Instytucja Zarządzająca RPOWP pozostawiała środek odwoławczy bez rozpatrzenia.

Po wyczerpaniu postępowania odwoławczego wnioskodawca mógł wnieść skargę do właściwego terytorialnie sądu administracyjnego, tj. w przypadku RPOWP - do Wojewódzkiego Sądu Administracyjnego w Białymstoku. Skarga miała charakter łańcuchowy, tj. możliwość jej wniesienia była uzależniona od wykorzystania dostępnej procedury odwoławczej na etapie przedsądowym. W wyniku rozpatrzenia skargi sąd mógł: uwzględnić skargę, oddalić skargę lub umorzyć postępowanie w sprawie.

Od zapadłego rozstrzygnięcia przed wojewódzkim sądem administracyjnym zarówno wnioskodawca jak i Instytucja Zarządzająca RPOWP mogli wnieść skargę kasacyjną do Naczelnego Sądu Administracyjnego w Warszawie. Stwierdzenie przez sad w trakcie procedury odwoławczej, iż ocena projektu została przeprowadzona w sposób naruszający prawo, skutkowało koniecznością jej powtórzenia (Łacny 2015). W tej sytuacji Instytucja Zarządzająca RPOWP była zobligowana do przeprowadzenia ponownej procedury odwoławczej. Z kolei prawomocne rozstrzygnięcie sądu administracyjnego, polegające na oddaleniu 
of complaint, rejecting the complaint or leaving the complaint without consideration, ended the appeal procedure and the procedure for the selection of projects (Kmieciak 2015). Very important was the fact that the scope of the judicial review exercised by the administrative courts concerned only examining whether the assessment of the application for funding was carried out in compliance with the law (Szubiakowski 2009). The review did not address the quality assessment of the project according to the selection criteria approved by the Monitoring Committee of the ROPPV.

The scope of the appeal procedure, especially in the initial phase of its implementation, put the applicants in a situation of lack of experience, limited allocations and lack of clear guidance on the interpretation of the applicable regulations (Perkowski 2009). All these negative factors were reflected in the practical application of the appeal procedure by the Managing Authority in terms of setting up the system for selection of tourism projects within Priority Axis III. Development of tourism and culture of the ROPPV.

According to the data presented in table 3 , within 4 calls for proposals for funding from the ROPPV's Measure 3.1. Development of regional tourism attractiveness 69 project proposals of a total value of co-financing of PLN 409,806,348.12 failed to pass the formal and quality assessment thresholds. In this regard, the applicants lodged 20 protests, which resulted in the decision of the Managing Authority skargi, odrzuceniu skargi lub pozostawieniu skargi bez rozpatrzenia, kończyło procedurę odwoławczą oraz procedurę wyboru projektów (Kmieciak 2015). Niezwykle istotny był fakt, iż zakres kontroli sprawowanej przez sądy administracyjne dotyczył wyłącznie zbadania czy ocena wniosku o dofinansowanie została przeprowadzona w sposób zgodny z prawem (Szubiakowski 2009). Kontrola sądowa w ogóle nie dotyczyła merytorycznej oceny spełnienia przez projekt kryteriów zatwierdzonych przez Komitet Monitorujący RPOWP.

Tak zaprojektowana procedura odwoławcza, zwłaszcza w początkowej fazie jej funkcjonowania, stawiała wnioskodawców w sytuacji ograniczonych alokacji, braku jasnych wytycznych w zakresie interpretacji obowiązujących przepisów oraz braku doświadczenia $w$ stosowaniu przyjętych rozwiązań (Perkowski 2009). Wszystkie te negatywne czynniki znalazły swoje odzwierciedlenie w praktyce stosowania przez Instytucję Zarządzającą procedury odwoławczej w zakresie ubiegania się o dofinansowanie projektów turystycznych w ramach Osi priorytetowej III. Rozwój turystyki i kultury RPOWP.

Jak wynika $\mathrm{z}$ danych zaprezentowanych $\mathrm{w}$ tabeli 3, w ramach 4 naborów wniosków o dofinansowanie z Działania 3.1. Rozwój atrakcyjności turystycznej regionu RPOWP na etapie oceny formalnej i merytorycznej negatywnie oceniono 69 projektów o łącznej wartości dofinansowania 409.806.348,12 zł. W tym zakresie wnioskodawcy wnieśli 20 protestów, z cze-

Table 3. Effectiveness of protests lodged under Measure 3.1. Development of regional tourism attractiveness of the ROPPV 2007-2013 (breakdown by calls for proposals)

Tabela 3. Skuteczność wnoszenia protestów w ramach Działania 3.1. Rozwój atrakcyjności turystycznej regionu RPOWP 20072013 (w rozbiciu na konkursy)

\begin{tabular}{|c|c|c|c|c|c|c|c|}
\hline \multirow[b]{2}{*}{$\begin{array}{l}\text { Call for pro- } \\
\text { posals/ Ter- } \\
\text { min naboru } \\
\text { wniosków }\end{array}$} & \multirow[b]{2}{*}{$\begin{array}{c}\text { Decision on } \\
\text { selection of } \\
\text { projects/ } \\
\text { Rozstrzy- } \\
\text { gnięcie }\end{array}$} & \multicolumn{2}{|c|}{$\begin{array}{c}\text { Formal assessment/ } \\
\text { Ocena formalna }\end{array}$} & \multicolumn{2}{|c|}{$\begin{array}{l}\text { Quality assessment/ } \\
\text { Ocena merytoryczna }\end{array}$} & \multicolumn{2}{|c|}{$\begin{array}{c}\text { Protest/ } \\
\text { Protest }\end{array}$} \\
\hline & & $\begin{array}{c}\text { Number } \\
\text { of applica- } \\
\text { tions } \\
\text { (pcs.)/ } \\
\text { Liczba } \\
\text { wniosków } \\
\text { (w szt.) }\end{array}$ & $\begin{array}{c}\text { Co-financing } \\
\text { (PLN)/ } \\
\text { Kwota dofinan- } \\
\text { so-wania (zł) }\end{array}$ & $\begin{array}{c}\text { Number } \\
\text { of applica- } \\
\text { tions } \\
\text { (pcs.)/ } \\
\text { Liczba } \\
\text { wniosków } \\
\text { (w szt.) }\end{array}$ & $\begin{array}{c}\text { Co-financing } \\
\text { (PLN)/ } \\
\text { Kwota dofinan- } \\
\text { so-wania (zł) }\end{array}$ & $\begin{array}{c}\text { Number } \\
\text { of applica- } \\
\text { tions } \\
\text { (pcs.)/ } \\
\text { Liczba } \\
\text { wniosków } \\
\text { (w szt.) }\end{array}$ & $\begin{array}{c}\text { Co-financing } \\
\text { (PLN)/ } \\
\text { Kwota dofinan- } \\
\text { so-wania (zł) }\end{array}$ \\
\hline \multirow{2}{*}{$\begin{array}{c}26.06 .2008- \\
04.08 .2008\end{array}$} & $\begin{array}{l}\text { Positive/ } \\
\text { Pozytywne }\end{array}$ & 24 & $100,029,962.00$ & 18 & $59,924,793.91$ & 0 & 0.00 \\
\hline & \begin{tabular}{|l|} 
Negative/ \\
Negatywne
\end{tabular} & 3 & $638,706.91$ & 6 & $35,911,407.23$ & 3 & $28,202,072.87$ \\
\hline \multirow{2}{*}{$\begin{array}{c}15.12 .2009- \\
05.02 .2010\end{array}$} & $\begin{array}{l}\text { Positive/ } \\
\text { Pozytywne }\end{array}$ & 32 & $132,714,802.88$ & 15 & $52,049,766.33$ & 0 & 0.00 \\
\hline & $\begin{array}{l}\text { Negative/ } \\
\text { Negatywne }\end{array}$ & 7 & $30,650,010.55$ & 17 & $99,920,365.77$ & 1 & $5,554,436.61$ \\
\hline \multirow{2}{*}{$\begin{array}{l}01.07 .2010- \\
31.08 .2010\end{array}$} & \begin{tabular}{|l|} 
Positive/ \\
Pozytywne
\end{tabular} & 20 & $99,313,668.63$ & 8 & $28,127,207.16$ & 1 & $3,513,629.80$ \\
\hline & $\begin{array}{l}\text { Negative/ } \\
\text { Negatywne } \\
\end{array}$ & 4 & $21,724,351.90$ & 12 & $70,998,136.73$ & 1 & $2,469,683.82$ \\
\hline \multirow{2}{*}{$\begin{array}{c}29.03 .2012- \\
09.05 .2012\end{array}$} & \begin{tabular}{|l|} 
Positive/ \\
Pozytywne
\end{tabular} & 28 & $174,812,888.41$ & 17 & $93,639,238.79$ & 1 & $1,170,000.00$ \\
\hline & \begin{tabular}{|l|} 
Negative/ \\
Negatywne
\end{tabular} & 9 & $77,777,225.08$ & 11 & $72,186,143.95$ & 13 & $81,214,831.52$ \\
\hline
\end{tabular}

Source: data from the Podlaskie Province Marshal's Office in Bialystok.

Źródło: dane Urzędu Marszałkowskiego Województwa Podlaskiego w Białymstoku. 
Table 4. Effectiveness of protests lodged under Measure 3.2. Investment support for tourism enterprises of the ROPPV 20072013 (breakdown by calls for proposals)

Tabela 4. Skuteczność wnoszenia protestów w ramach Działania 3.2. Wsparcie inwestycyjne przedsiębiorstw z branży turystycznej RPOWP 2007-2013 (w rozbiciu na konkursy)

\begin{tabular}{|c|c|c|c|c|c|c|c|}
\hline \multirow[b]{2}{*}{$\begin{array}{l}\text { Call for pro- } \\
\text { posals/ Ter- } \\
\text { min naboru } \\
\text { wniosków }\end{array}$} & \multirow[b]{2}{*}{$\begin{array}{c}\text { Decision on } \\
\text { selection of } \\
\text { projects/ } \\
\text { Rozstrzy- } \\
\text { gnięcie }\end{array}$} & \multicolumn{2}{|c|}{$\begin{array}{c}\text { Formal assessment/ } \\
\text { Ocena formalna }\end{array}$} & \multicolumn{2}{|c|}{$\begin{array}{l}\text { Quality assessment/ } \\
\text { Ocena merytoryczna }\end{array}$} & \multicolumn{2}{|c|}{$\begin{array}{c}\text { Protest/ } \\
\text { Protest }\end{array}$} \\
\hline & & $\begin{array}{c}\text { Number } \\
\text { of applica- } \\
\text { tions } \\
\text { (pcs.)/ } \\
\text { Liczba } \\
\text { wniosków } \\
\text { (w szt.) }\end{array}$ & $\begin{array}{c}\text { Co-financing } \\
\text { (PLN)/ } \\
\text { Kwota dofinan- } \\
\text { so-wania (zł) }\end{array}$ & $\begin{array}{c}\text { Number } \\
\text { of applica- } \\
\text { tions } \\
\text { (pcs.)/ } \\
\text { Liczba } \\
\text { wniosków } \\
\text { (w szt.) }\end{array}$ & $\begin{array}{c}\text { Co-financing } \\
\text { (PLN)/ } \\
\text { Kwota dofinan- } \\
\text { so-wania (zł) }\end{array}$ & $\begin{array}{c}\text { Number } \\
\text { of applica- } \\
\text { tions } \\
\text { (pcs.)/ } \\
\text { Liczba } \\
\text { wniosków } \\
\text { (w szt.) }\end{array}$ & $\begin{array}{c}\text { Co-financing } \\
\text { (PLN)/ } \\
\text { Kwota dofinan- } \\
\text { so-wania (zł) }\end{array}$ \\
\hline \multirow{2}{*}{$\begin{array}{l}01.04 .2008- \\
30.05 .2008\end{array}$} & $\begin{array}{l}\text { Positive/ } \\
\text { Pozytywne }\end{array}$ & 30 & $72,097,460.55$ & 11 & $32,359,941.02$ & \multirow{2}{*}{$\begin{array}{c}\text { no data/ } \\
\text { brak danych }\end{array}$} & \multirow{2}{*}{$\begin{array}{c}\text { no data/ } \\
\text { brak danych }\end{array}$} \\
\hline & $\begin{array}{l}\text { Negative/ } \\
\text { Negatywne }\end{array}$ & 33 & $37,855,989.45$ & 19 & $39,737,519.53$ & & \\
\hline \multirow{2}{*}{$\begin{array}{c}26.11 .2009- \\
04.02 .2010\end{array}$} & \begin{tabular}{|l|} 
Positive/ \\
Pozytywne
\end{tabular} & 31 & $65,205,125.30$ & 14 & $33,678,927.62$ & 0 & 0.00 \\
\hline & \begin{tabular}{|l|} 
Negative/ \\
Negatywne
\end{tabular} & 11 & $23,595,248.47$ & 17 & $31,216,107.10$ & 10 & $24,167,512.73$ \\
\hline \multirow{2}{*}{$\begin{array}{c}12.08 .2010- \\
30.09 .2010\end{array}$} & \begin{tabular}{|l|} 
Positive/ \\
Pozytywne
\end{tabular} & 24 & $67,004,820.93$ & 9 & $25,989,729.07$ & 1 & $2,682,164.58$ \\
\hline & \begin{tabular}{|l|} 
Negative/ \\
Negatywne
\end{tabular} & 21 & $38,860,604.67$ & 15 & $38,332,927.28$ & 18 & $44,767,564.84$ \\
\hline \multirow{2}{*}{$\begin{array}{l}17.11 .2011- \\
12.01 .2012\end{array}$} & \begin{tabular}{|l|} 
Positive/ \\
Pozytywne
\end{tabular} & 12 & $37,164,685.83$ & 7 & $23,824,571.38$ & 0 & 0.00 \\
\hline & \begin{tabular}{|l|} 
Negative/ \\
Negatywne
\end{tabular} & 7 & $10,675,384.39$ & 5 & $12,734,757.05$ & 7 & $13,279,759.21$ \\
\hline \multirow{2}{*}{$\begin{array}{c}03.08 .2012- \\
17.09 .2012\end{array}$} & $\begin{array}{l}\text { Positive/ } \\
\text { Pozytywne }\end{array}$ & 17 & $43,837,271.59$ & 11 & $23,886,041.27$ & 0 & 0.00 \\
\hline & $\begin{array}{l}\text { Negative/ } \\
\text { Negatywne }\end{array}$ & 7 & $17,441,904.50$ & 6 & $19,694,041.17$ & 9 & $27,925,235.66$ \\
\hline \multirow{2}{*}{$\begin{array}{l}15.11 .2013- \\
24.01 .2014^{*}\end{array}$} & $\begin{array}{l}\text { Positive/ } \\
\text { Pozytywne }\end{array}$ & 11 & $22,200,187.35$ & 6 & $16,094,773.11$ & 0 & 0.00 \\
\hline & \begin{tabular}{|l|} 
Negative/ \\
Negatywne \\
\end{tabular} & 7 & $8,897,071.34$ & 4 & $5,392,242.71$ & 4 & $4,643,865.57$ \\
\hline
\end{tabular}

* Within the call for proposals lasting from 15 November 2013 to 24 January 2014 one application was withdrawn by the applicant during the quality assessment./ * W ramach konkursu trwającego od 15.11.2013 r. do 24.01.2014 r. jeden wniosek o dofinansowanie został wycofany przez wnioskodawcę w trakcie oceny merytorycznej

Source: data from the Podlaskie Province Marshal's Office in Bialystok.

Źródło: dane Urzędu Marszałkowskiego Województwa Podlaskiego w Białymstoku.

(of a value of co-financing of PLN 4,683,629.80) to include only 2 of them on the list of projects assessed positively. Detailed information obtained from the Podlasie Province Marshal's Office in accordance with the procedure stipulated by the Act on Access to Public Information indicates that the Managing Authority does not have any data on the applications for reconsideration concerning the calls for proposals organised in the years 2008-2010. However, within the framework of the call for proposals conducted from 29 March 2012 to 9 May 2012 no applications for reconsideration were submitted by the applicants.

Slightly worse situation in terms of the efficiency of the appeal procedure was noted in the case of Measure 3.2. Investment support for tourism enterprises. During 6 calls for proposals the Managing Authority considered that as many as 86 projects did not correspond to the formal assessment criteria. go w wyniku decyzji Instytucji Zarządzającej tylko 2 (o wartości dofinansowania 4.683.629,80 zł) trafiły na listę projektów ocenionych pozytywnie. Z informacji uzyskanej z Urzędu Marszałkowskiego Województwa Podlaskiego w trybie dostępu do informacji publicznej wynika, iż nie dysponuje on danymi dotyczącymi wniosków o ponowne rozpatrzenia sprawy dla konkursów ogłoszonych w latach 2008-2010. W ramach naboru wniosków o dofinansowanie przeprowadzonego od 29 marca 2012 r. do 9 maja 2012 r. nie wpłynął żaden wniosek o ponowne rozpatrzenia sprawy.

Nieco gorzej sytuacja w zakresie procedury odwoławczej przedstawia się w przypadku Działania 3.2. Wsparcie inwestycyjne przedsiębiorstw z branży turystycznej RPOWP. W trakcie 6 naborów wniosków o dofinansowanie Instytucja Zarzadzająca uznała, że aż 86 projektów nie odpowiada formalnym kry- 
Within the framework of the appeal procedure, 49 protests were lodged, of which only 1 (of the total value of co-financing of PLN 2,279,839.88) was considered eligible by the Managing Authority (table 4). As far as the second pre-trial stage of the appeal procedure was concerned, the applicants submitted 22 applications for reconsideration, none of which ended in putting a project proposal on the list of projects assessed positively.

According to the information provided by the Podlaskie Province Marshal's Office, neither of the applicants under Priority Axis III. Tourism and culture development, who initiated the pre-trial stage of the proceedings, decided to submit a complaint to the Province Administrative Court in Bialystok. Therefore, it can be concluded that the judicial phase of the appeal procedure was not applicable in the case of co-financing projects in the field of tourism from the resources available from the ROPPV.

\section{Conclusions}

On the basis of the results of analysis of the appeal procedure within the implementation of Priority Axis III. Tourism and culture development of the ROPPV it can be stated that it is impossible to clearly determine the degree of its effectiveness because it was not applied in its full extent. The main objective of the appeal procedure, functioning in the form of specific provisions of the system of implementation of the ROPPV, was to provide the applicants with sufficient legal protection against a non-objective conduct of assessment of their projects. Under this protection, the applicants were entitled to use the mechanism of verification consisting of two stages: the pre-trial stage and the stage of the proceedings before the administrative courts. In the case of failure of the provisions for appeal, the Managing Authority could finance subsequent projects from a reserve list.

A certain disadvantage of the appeal procedure consists in the fact that even in the case of a positive outcome of the remedy, an applicant had no guarantee that his project will be involved in the distribution of the European Union funds under the ROPPV. In such cases the project was put on the list of projects assessed positively, receiving only a conditional declaration of its co-financing. Furthermore, an appeal by the applicant did not result in holding by the Managing Authority the contract procedures concerning the other applicants, whose projects were recommended for co-financing. In a situation where at any stage of the appeal procedure the funds for implementation of a measure were exhausted, the Managing Authority simply left a legal remedy without consideration.

It should be also noted that none of the applicants under Priority Axis III. Tourism and culture development of the ROPPV decided to exercise their right regarding the use of the judicial stage of the appeal procedure, involving the proceedings before the competent administrative courts. However, many doubts about the potential effectiveness of this mode teriom oceny. W ramach procedury odwoławczej wpłynęło 49 protestów, z których tylko 1 (o wartości dofinansowania 2.279.839,88 zł) został uwzględniony przez Instytucję Zarządzającą (tabela 4). W zakresie II etapu przedsądowego procedury odwoławczej wnioskodawcy wnieśli 22 wnioski o ponowne rozpatrzenie sprawy, z których żaden nie zakończył się skierowaniem projektu na listę projektów ocenionych pozytywnie.

Zgodnie z informacjami uzyskanymi z Urzędu Marszałkowskiego Województwa Podlaskiego, żaden $\mathrm{z}$ wnioskodawców w ramach Osi priorytetowej III. Rozwój turystyki i kultury, którzy skorzystali z przedsądowego etapu procedury odwoławczej, nie zdecydował się na złożenie skargi do Wojewódzkiego Sądu Administracyjnego w Białymstoku. Można zatem stwierdzić, iż sądowy etap procedury odwoławczej nie miał praktycznego zastosowania $\mathrm{w}$ przypadku ubiegania się o dofinansowanie projektów z zakresu turystyki ze środków dostępnych w RPOWP.

\section{Podsumowanie}

W wyniku przeprowadzonych analiz w odniesieniu do procedury odwoławczej $w$ ramach implementacji Osi priorytetowej III. Rozwój turystyki i kultury RPOWP można stwierdzić, iż nie da się jednoznacznie określić stopnia jej skuteczności, gdyż nie miała ona zastosowania w pełnym zakresie. Zasadniczym celem procedury odwoławczej, funkcjonującej w kształcie określonym postanowieniami systemu realizacji RPOWP, było zapewnienie wnioskodawcom ochrony prawnej przed nieobiektywnym procesem oceny ich projektów. W ramach tej ochrony wnioskodawcy mieli możliwość skorzystania z mechanizmu weryfikacji złożonego z dwóch etapów: etapu przedsądowego i etapu postępowania przed sądami administracyjnymi. W przypadku niewykorzystania przez wnioskodawców rezerwy na odwołania, Instytucja Zarządzająca mogła z tej kwoty finansować kolejne projekty z listy rezerwowej.

Pewien mankament procedury odwoławczej stanowił fakt, iż nawet w przypadku pozytywnego rozpatrzenia środka odwoławczego wnioskodawca nie miał żadnej gwarancji, że jego projekt będzie brał udział w podziale środków unijnych w ramach RPOWP. W takiej sytuacji projekt trafiał na listę projektów ocenionych pozytywnie, uzyskując jedynie warunkową deklarację jego dofinansowania. Co więcej, wniesienie środka odwoławczego przez wnioskodawcę nie wstrzymywało zawierania umów przez Instytucję Zarządzającą z innymi wnioskodawcami, których projekty zostały wybrane do dofinansowania. W sytuacji gdy na jakimkolwiek etapie procedury odwoławczej środki na realizację danego działania zostały wyczerpane, Instytucja Zarządzająca po prostu pozostawiała środek odwoławczy bez rozpatrzenia.

Należy przy tym nadmienić, iż żaden z wnioskodawców w ramach Osi priorytetowej III. Rozwój turystyki i kultury RPOWP nie zdecydował się na realizację swego uprawnienia w zakresie skorzystania z etapu sądowego procedury odwoławczej, obejmującego postępowanie przed właściwymi sądami ad- 
of appeal leaves the fact that the eventual judgment would not concern the issue of the quality assessment of a project proposal, which basically is the essence of the assessment process. The efficiency of the procedure of assessing applications for funding could not yet constitute a superior value compared to the fairness and objectivity of the assessment itself. For these reasons, it is impossible to clearly determine the degree of effectiveness of the appeal procedure concerning the process of application for the cofinancing of tourism projects under the ROPPV 20072013 because the mechanism of verification of the correctness of projects' assessment was not applied in its full extent. ministracyjnymi. Jednakże wiele wątpliwości co do potencjalnej skuteczności tego trybu odwoławczego pozostawia fakt, iż ewentualne rozstrzygnięcie sądu nie dotyczyłoby kwestii merytorycznej oceny projektu, która zasadniczo stanowi istotę samego procesu oceniania. Sprawność przeprowadzenia procedury oceny wniosków o dofinansowania nie może przecież stanowić wartości nadrzędnej względem rzetelności i obiektywizmu samej oceny. Z powyższych względów nie da się jednoznacznie określić stopnia skuteczności procedury odwoławczej w przedmiocie ubiegania się o dofinansowanie projektów turystycznych w ramach RPO WP 2007-2013 jako mechanizmu weryfikacji prawidłowości przeprowadzenia oceny projektów, gdyż nie miała ona zastosowania w pełnym zakresie.

\section{References/ Literatura:}

1. Dziurbejko T., Mnich K., Mossakowski M., Perkowski M. (2010), Prawo zarządzania projektami finansowanymi z funduszy europejskich. Wydawnictwo Wolters Kluwer, Warszawa.

2. Kmieciak Z. (2015), Idea procedur administracyjnych trzeciej generacji (na przykładzie postępowania w sprawach dofinansowania projektów w ramach programów operacyjnych). Państwo i Prawo, nr 5, s. 3-18.

3. Łacny J. (2015), Ochrona praw podstawowych w wydatkowaniu funduszy Unii Europejskiej. Państwo i Prawo, nr 12, s. $25-45$.

4. Suwaj R., Perkowski M. (2010), Koncepcja zapobiegania bezczynności w postępowaniu administracyjnym. Fundacja Prawo i Partnerstwo, Białystok.

5. Perkowski M. (2009), Monitoring procedury odwoławczej w systemie wdrażania funduszy europejskich na Podlasiu. Fundacja Prawo i Partnerstwo, Białystok.

6. Perkowski M. (2010), Procedura odwoławcza w systemie wdrażania funduszy europejskich. Wydawnictwo Wolters Kluwer, Warszawa.

7. Regionalny Program Operacyjny Województwa Podlaskiego na lata 2007-2013.

8. Szczegółowy Opis Priorytetów Regionalnego Programu Operacyjnego Województwa Podlaskiego na lata 2007-2013.

9. Szubiakowski M. (2009), Postępowanie w sprawie rozdziału środków w ramach polityki rozwoju oraz sq̨dowa kontrola w tych sprawach. Zeszyty Naukowe Sądownictwa Administracyjnego, nr 4, s. 31-39.

\section{Websites/ Strony internetowe:}

10. Sprawozdanie okresowe z realizacji Regionalnego Programu Operacyjnego Województwa Podlaskiego na lata $2007-2013$ za I półrocze 2015 r., www.rpowp.wrotapodlasia.pl (data dostępu: 18.05.2016).

11. Strategia Rozwoju Województwa Podlaskiego do roku 2020, Załącznik do Uchwały Nr XXXV/438/06 Sejmiku Województwa Podlaskiego z dnia 30 stycznia 2006 r., www.strategia.wrotapodlasia.pl (data dostępu: 18.05.2016). 